\title{
Guilherme de Almeida e o lugar do haicai na poesia brasileira
}

\section{FABRícIo MARQUES}

Doutor em literatura comparada pela Faculdade de Letras da UFMG e professor de edição jornalística do Centro Universitário de Belo Horizonte (UniBH). Autor, dentre outros, de "Aço em flor: a poesia de Paulo Leminski (Autêntica, 2001).

Resumo: A forma poética do haicai tornou-se popular no Brasil a partir da metade do século passado, com a decisiva contribuição de Guilherme de Almeida. Este artigo busca entender a posição dessa forma oriental dentro da produção poética no país, tendo em vista que a própria crítica às vezes se confunde, percebendo como haicai qualquer poema sintético.

Palavras-chave: Guilherme de Almeida; poesia; haicai
Abstract: The poetic form of the haicai became popular in Brazil since the 1950 years from the past contury, with the contribution from Guilherme de Almeida. This article talks about the position of this oriental form inside the brazilian poetic production, in the same time that literary criticsm itself sometime confuses haicai and sintetic poem.

Key words: Guilherme de Almeida; poetry; haicai 

"Lá [no Oriente], onde nasce a luz, nasceram a humanidade e a sabedoria, e com elas, a sua mais luminosa, mais humana e mais sábia forma: a poesia", escreve Guilherme de Almeida, no artigo "Os meus haicais", publicado em 28 de fevereiro de 1937, no jornal $O$ Estado de $S$. Paulo. E continua:

E, como o sol, vem ela vindo para o Ocidente, e, como ele, talvez, brilhando mais, tanto mesmo que obrigou os homens a fechar os olhos que não puderam resistir ao clarão. Incapazes de a contemplarem, dizem eles, agora, nestas longitudes, que "a poesia morreu". Não morreu: continuou a descer, com o sol; teve o seu crepúsculo; e está agora, estará sempre renascendo no Levante ${ }^{1}$.

Tendo estreado na poesia duas décadas antes, em 1917, o poeta não tem dúvidas, ao dirigir o olhar para o Oriente: "Olho para aí e aí descubro, no seu aspecto mais simples e, pois, mais exato, a poesia: toda consubstanciada no haicai".

Mas, o que é haicai? Para Guilherme, o haicai é a poesia reduzida à expressão mais simples. "Um mero enunciado: lógico, mas inexplicado. Apenas uma pura emoção colhida ao voo furtivo das estações que passam, como se colhe uma flor na primavera, uma folha morta no outono, um floco de neve no inverno...", diz o poeta. E completa: "Emoção concentrada numa síntese fina, poeticamente apresentada em dezessete sons, repartidos por três versos: o primeiro de cinco sílabas, o segundo de sete e o terceiro de cinco. Impressão breve, mas tão extensível, desdobrável: pastille fumante...".

Vinte anos de poesia - uns trinta livros de versos escritos e uns vinte publicados - levam-me hoje à conclusão calma (que não é uma negação à minha nem um sarcasmo à obra dos outros) de que não há ideia poética, por mais complexa, que, despida de roupagens atrapalhantes, lavada de toda excrecência, expurgada de qualquer impureza, não caiba estrita e suficientemente, em 
última análise, nas dezessete sílabas de um haicai. $O$ melro, $O$ navio negreiro, $A$ vingança da porta, $o$ Ouvir estrelas, os trinta e três sonetos do meu Nós (no caso, não é pretensão, senão mero estoicismo, o colocar-me em tão superior companhia) poderiam ter sido reduzidos a simples haicais².

Para Guilherme, aderir ao haicai é uma questão de coragem: "coragem de renunciar a si mesmo, a uma porção de enfeites, de supérfluos mais ou menos bonitos, para só manter um essencial". O haicai é o contraponto objetivo à dispersiva poesia ocidental: "Ao descrever o primeiro, maravilhoso verso da sua "Brise Marine", Mallarmé fez um haicai: "La chair est triste, hélas! et j’ai là tous les livres!'. Mas não teve coragem de parar aí: sob esse essencial, alinhou quinze supérfluos. É a poesia dispersiva do Ocidente."

Alguns dias antes de escrever esse artigo, Guilherme se perguntara: será possível o haicai em outra língua que não a japonesa? "Franceses de hoje, como Jules Supervielle, Tristan Derime, Robert de Souza, Fernand Lot; alemães, como Ernst Wohlfarth, Otto Thonak, F. Rumpf; e ingleses, e italianos e até já alguns patrícios meus, têm tentado o haicai, mas sem disciplina, sem um eficiente trabalho de aclimatação, uma justa observância e adaptação dos processos e ritmos originais: apenas livre-men-te".

Em entrevista a Genésio Pereira Filho, publicada na Gazeta Magazine, de 29 de setembro de 1941, e reproduzida no boletim Imprensa Paulista, órgão informativo da Associação Paulista de Imprensa, número 41, de julho/dezembro de 1980, Guilherme explica:

Quem revelou autorizadamente o haicai no Ocidente foi Georges Boneau. A forma poética japonesa fez furor. Poetas franceses, ingleses, alemães, norte-americanos puseram-se a fazer haicai. Mas, sem a rígida disciplina nipônica, mais ou menos ao acaso. Foi diante disso que eu tive a ideia nesse ano de 1937 de tentar uma transplantação rigorosa, submetida à disciplina 
rígida, do haicai para o português. Descobri que os dois metros - de cinco e de sete sílabas eram familiares aos nossos poetas: o de cinco o metro habitual das cantigas infantis, de roda ou de ninar. Por exemplo: Tutu Maramoa, e o de sete, o verso essencialmente popular, das trovas ou redondilhas. Note-se que a métrica japonesa corresponde exatamente à nossa, pois é também silábica. $\mathrm{O}$ japonês não rima, não conhece a rima. Mas usa e abusa de aliterações e onomatopeias (apud PEREIRA FILHO, 1941).

Virtuoso do verso, Guilherme estava preocupado em como transportar a forma japonesa para o Brasil, sem feri-la na identidade. Tinha na cabeça a afirmação de Takahama Kyoshi, durante um jantar de que participara em 5 de maio de 1936, no P.E.N. Club de Londres: "Penso que não é possível tentar a forma de dezessete sons em língua alguma que não a japonesa. O Poeta que quisesse escrever poemas como os haicais bem andaria em escolher uma pequena forma poética que melhor se adaptasse à sua língua materna".

Contudo, discordando de Kyoshi, Guilherme achava que todos os elementos e todos os processos do haicai podem ser encontrados e empregados na poesia brasileira, geograficamente antípoda da sua: os extremos se tocam.

As mesmas analogias plásticas que Georges Bonneau (o verdadeiro revelador do haicai no Ocidente) notou entre a poesia japonesa e francesa, descubro, e mais estreitas ainda, entre aquela e a nossa, a luso-brasileira. Estas, por exemplo:

1) A poesia é silábica (isto é, conta sílabas e não acentos) como a nossa.

2) São comuns a ambas as línguas as "sonoridades elementares" ou "vogais": a,e,i,o,u.

3) Os ritmos ímpares "elementares" (de 5 e de 7 sílabas), peculiares à língua japonesa, também o são à nossa. $O$ verso segundo do haicai, o de 7 sílabas, é a redondilha, que nasceu com a nossa poesia na Galiza, fez-se a medida clássica de todos os nossos importados "romances", a música 
natural da nossa "trova popular", o diapasão da modinha capadócia, a nossa expressão folclórica por excelência, e mesmo a medida inconsciente, automática, da nossa fala. Diz-se até que nós falamos, sem o querer, por septissílabos ${ }^{3}$.

Dessa última analogia davam conta, segundo Guilherme, os provérbios e ditos populares, como "Nem tudo o que é luz é ouro" ou "Água mole em pedra dura tanto dá até que fura". Outro ritmo do haicai - o verso de cinco sílabas - era também comum na língua portuguesa. "Vem dos estribilhos medievais, dos refrões dos Cancioneiros. D'amores ei ma (Ruy Paesde Ribella); Os amores ei (Pero Alcobo) etc.". Para exemplificar, Guilherme cita, entre outros, uma toada musical nas "serraninhas" brasileiras:

Papagaio louro

Do bico dourado

${ }^{3}$ Almeida (1937).

Leva-me esta carta

Ao mesmo namorado

Ou este, das nossas tradicionais "Pastorelas":

Bela Pastorinha.

Que fazeis aqui?

Pastoreando o gado

Que eu aqui perdi

Ou, ainda, a cadência favorita das nossas "rondas" infantis:

Tutu Marambaia.

Saia do telhado.

Deixe este menino

Dormir sossegado.

Assim, a partir desses recursos técnicos, somados às onomatopeias e aliterações que caracterizam epigramas japoneses dos dezessete sons, e sem prescindir do "senso do símbolo" de cunho ideogramático, Guilherme de Almeida procurou acrescentar um toque pessoal ao haicai. 
Em suas palavras: conferir "à minúscula pastilha nipônica um dourado todo nosso - a rima - , a única corda que conseguimos acrescentar à lira dos gregos"4.

Tal é a fórmula do "seu" haicai: os três versos japoneses, na sua ordem original: 5-7-5; o primeiro, rimando com o terceiro; o segundo, um septissílabo, com uma rima interna: a segunda sílaba rimando com a sétima - "o que não se pode dizer que seja uma extravagância numa língua em que tal artifício frequentemente aparece, como nos provérbios populares": "Por fora, bela viola, / por dentro, pão bolorento"; e processo "que cria um verso também de cinco sílabas pela subtração de duas sílabas a que a rima força $(7-2=5)$, verso esse que se integra facilmente na música dominante da pequena estrofe, que é a música do pentassílabo; sentir, pensar e não dizer: somente insinuar"

Guilherme de Almeida publicou 43 haicais em Poesia vária (1947). Outros 14 saíram em $O$ anjo de sal (1951), da seguinte forma: na primeira parte, Da vida, sete formam os Haicais da colina; há 6 haicais para Campos do Jordão. Na terceira e última parte, Da morte, há a solitária Elegia, dedicada a Koso Itigé, que, "na Poesia, se chamou 'Neve do crepúsculo'”.

Em Os meus haicais, Guilherme de Almeida considerou importante tecer comentários sobre algumas de suas criações nipo-paulistanas, as quais, naquele momento, ele ainda considerava apenas como uma experiência ("e mais nada") e que vale a pena reproduzir, mesmo alertando que, na visão dos japoneses, o haicai não deveria ser explicado. Mas Guilherme viu a necessidade de comentar sobre eles, visto que o público brasileiro, àquela época, experimentava um contato com o haicai pela primeira vez, em termos de comunicação de massa ${ }^{6}$ :
${ }^{4}$ Almeida (1937).

${ }^{5}$ Almeida (1937).

6 Toda esta sequência de haicais com respectivos comentários está em Almeida (1937).

\section{CARIDADE}

Desfolha-se a rosa parece até que floresce o chão cor-de-rosa. 
(“A flor, que se desfolha, é bem uma lição moral de alta caridade: dir-se-ia que ela se despe do que é seu, que ela toda se dá à terra humilde, para que o pobre chão, a seus pés, pense que também é capaz de florir.")

AQUELE DIA

Borboleta anil

que um louro alfinete de ouro

espeta em Abril

("Um dia do passado - céu azul varado de sol fino de ouro - que ficou numa vida, sugere a ideia da borboleta que os colecionadores espetam no quadro melancólico. Colorida e linda ainda, parece viva: mas está morta, bem morta.")

\section{HISTÓRIA DE ALGUMAS VIDAS}

Noite. Um silvo no ar.

Ninguém, na estação. E o trem

passa sem parar.

("O haicai japonês acompanha o processo: está sempre "à la Page", explora frequentemente temas modernos (a aviação, o cinema, o rádio...). Aqui está um de inspiração mecânica, atual: todo um romance o das imperceptíveis criaturas pelas quais a vida parece que passa sem nada deixar nem levar, como os trens de ferro pelas estaçõezinhas insignificantes onde ninguém embarca nem desembarca.")

\section{NÓS DOIS}

Chão humilde. Então

riscou-o a sombra de um voo.

"Sou céu" - disse o chão

("Uma definição do amor: uma ave voa alto, entre a terra e o sol; a sua sombra projeta-se no chão, assustando-o, movimentando-o todo, e vai-se. Ela é a ave. Ele, o chão extático.”) 
N.W.

Dilaceramentos.

Pois tem espinhos também

a rosa-dos-ventos.

(“É das nossas lágrimas muitas vezes que nascem as mais brilhantes alegrias. Pois não é nas gotinhas de orvalho, de manhã, que o sol mais brilha? Desse pensamento derivou este haicai.")

QUIRIRI

Calor. Nos tapetes

tranquilos da noite, os grilos

fincam alfinetes.

("Uma imagem do silêncio das nossas caatingas — o silêncio agudo, todo aliterado em 'ii', feito todo de tinidos de insetos sutis.")

VELHICE

Uma folha morta.

Um galho no céu grisalho.

Fecho a minha porta.

("Descrição da velhice - a partida das ilusões como folhas de outono; o gesto sem verdes, sem esperanças, para o céu; os cabelos grisalhos; a solidão e o egoísmo dos velhos.")

O HAICAI

Lava, escorre, agita

a areia. E enfim, na bateia,

fica uma pepita.

("Um último exemplo: a definição do haicai num haicai. Que é ele, afinal? - o grãozinho de ouro que os lavageiros pacientes descobrem lavando a terra aurífera e deixando escorrer a ganga impura.")

Aí está, bem marcado, com sua identidade própria, o haicai de Guilherme de Almeida. Se hoje essa forma poética 
7 As informações sobre os haicais de Drummond estão em Guttilla (2008). é tão popular no Brasil, deve-se muito esse fato ao poeta paulista. Seria importante, agora, ter contato com outros criadores haicaístas, para perceber de modo mais nítido as especificidades do haicai guilhermiano. Nomes como o de Carlos Drummond de Andrade, que publicou os seus haicais pela primeira vez na revista Para todos, em 27 de junho de 1925, sob o título de Hai-kais urbanos. Na assinatura, o poeta omitira o "de Andrade". Passados setenta e dois anos da publicação, os poemas foram novamente divulgados nas páginas de $O$ Estado de $S$. Paulo, em matéria de Norma Couri, de 16 de agosto de 1997. Os originais, endereçados a Gilberto Mendonça Teles, amigo e confidente do poeta mineiro, encontram-se no Arquivo Museu de Literatura da Casa de Rui Barbosa, no Rio de Janeiro ${ }^{7}$.

Em um deles, Drummond repercute o tema do poema "Domingo", de Pauliceia desvairada, de Mário de Andrade, publicada em 1922 ("Central. Drama de Adultério. / A Bertini arranca os cabelos e morre. / Fugas... Tiros... Tom Mix!/ Amanhã fita alemã...!"):

Na escuridão da sala,

Tom Mix apareceu

E meus braços fracos te apertaram.

Em outro, antecipando a temática social que marcará, especialmente, $A$ rosa do povo, Drummond comporá um de seus mais singelos haicais:

Não tenho dinheiro no banco, Porém,

Meu jardim está cheio de rosas.

Ao publicar Alguma poesia, em 1930, Drummond rejeitará seus haicais primitivos. Um único poemeto fará parte de sua primeira obra:

COTA ZERO

Stop!

A vida parou

Ou foi o automóvel? 
Drummond voltaria aos poemas japoneses em outras oportunidades: em Corpo, de 1984, aparecem dois haicais. Um ano depois, o poeta divulga 20 haicais, escritos em 1968. Agrupados sob o título de Miniversos, os poemas aparecerão em Amar se aprende amando. Em seu crepúsculo, Drummond publicará seus últimos haicais em Farewell. Reunidos em Arte em exposição, os poemas foram criados a partir da observação de pinturas da predileção do autor, como este:

PIETÁ (Miguel Ângelo)

Dor é incomunicável.

O mármore comunica-se, Acusa-nos a todos.

Em 1939, o poeta paulista Jorge Fonseca Jr. publicou um livro de haicais intitulado Roteiro lírico. Quase todos os haicais desse livro contêm um "motivo ornamental brasílico", tirado da natureza brasileira, e este foi o primeiro movimento do haicai brasileiro para incorporar a idéia de "kigo" ou palavra de estação ${ }^{8}$. Um haicai de Jorge Fonseca Jr.:

Fundo de quintal...

Silêncio. No velho muro, Uns cacos de sol.

Em 1941, a poeta paranaense Helena Kolody publicou seus primeiros haicais. Em seu livro Música submersa (1945) aparece o haicai "Pereira em flor":

De grinalda branca, Toda vestida de luar A pereira sonha.

Anos mais tarde, Helena tornou-se haijin (pessoa que cultua o haicai), com o nome artístico de Reika ("perfume da poesia"), concedido em 1993 pela sociedade japonesa.

Um outro nome que ocorre é o do escritor Millôr Fernandes. Seu interesse pelo haicai, como forma de expressão direta e econômica, começou em 1957, quando 
escrevia uma seção de humor "Pif-Paf" da revista $O$ Cruzeiro, nos anos de 1950. Seu primeiro haicai data de 1959. Passou a compor alguns quase semanalmente, usando, porém, apenas os três versos da forma original, sem se preocupar com o número de sílabas. No livro Haikai ele reúne sua produção, que vai desse marco inicial até 1986. Os haicais de Millôr geralmente não têm título, como este:

Eu vim com pão, azeite e aço;

Me deram vinho, apreço, abraço:

O sal eu faço.

Ou este:

Passeio aflito;

Tantos amigos

Já granito.

Outro nome de destaque é o de Paulo Leminski, que, segundo Iura (2000), popularizou o haicai e preparou o terreno para o grande salto do haicai nos anos de 1980 . O grande mérito de Leminski foi trazer o haicai da torre de marfim do lirismo em que se encontrava para a vida cotidiana. Os haicais leminskianos são muito livres na forma, sem preocupação com o número de sílabas. E, na maioria delas, há a rima entre o primeiro e o terceiro versos, como nestes exemplos:

estrela cadente eu olho

o céu partiu

para uma carreira solo

morreu o periquito

a gaiola vazia

esconde um grito.

para fazer uma teia num minuto

a aranha cobra pouco

apenas um mosquito.

tudo dito,

nada feito,

fito e deito. 
Em 2003, o escritor Miguel Sanches Neto lançou Abandono, livro apenas com haicais, dentre os quais se destaca este:

\author{
Vaga-lume luzindo \\ Me ilumino \\ Com o mínimo
}

A lista de praticantes do haicai não é pequena. Como se pode ver, há uma longa tradição no Brasil, como atesta Edson Kenji Iura (2000). Segundo Iura, durante os tempos de Bashô, o Brasil era uma colônia de Portugal. Enquanto isso, os jesuítas catequizavam os povos ao redor do mundo, seguindo o rastro dos navegadores portugueses e espanhóis. Os portugueses foram os primeiros europeus a chegar ao Japão, em 1543. E em 1604 o padre João Rodrigues, em seu trabalho "Arte da lingoa de Iapam", deu a primeira notícia do haicai ao mundo:

9 Apud Iura (2000).

Ha hua sorte de versos a modo de renga que se chama: Faicai, de estillo mais baixo \& o verso he de palavras ordinarias, \& facetas a modo de verso macarronico, \& este modo de Renga, posto que nam tem tantos preceitos como a verdadeira, o numero de versos pode ser o mesmo. E pode começar pello segundo verso de sete sete, que se chama Tçuquecu, \& continuar com cinco sete cinco'.

Apesar desse registro tão antigo, não há outras ocorrências importantes na história do haicai no Ocidente até a segunda metade do século XIX, quando novos viajantes ocidentais redescobriram o Japão, que se abria para o mundo após dois séculos de autorreclusão.

Dentre estes visitantes, os franceses merecem atenção especial por causa da forte presença da cultura francesa no Brasil. A segunda língua da elite brasileira era o francês e era através de livros escritos em francês ou traduzidos para essa língua que os brasileiros se mantinham informados sobre o que acontecia no mundo. Entre as novidades trazidas por esses livros, estava o haicai japonês. 
E um dos principais divulgadores do haicai na Europa era Paul-Louis Couchoud, que escreveu Sages et poètes d'Asie, em 1918.

Este título é citado nominalmente no rodapé do prefácio do livro Trovas populares brasileiras, escrito por Afrânio Peixoto em 1919. Neste prefácio, apesar de ser de um livro sobre trovas, Afrânio faz uma comparação destas com o haicai japonês, citando pela primeira vez nomes como Bashô, Moritake e Buson, e traduzindo alguns haicais para o português. Este livro é considerado a primeira introdução escrita ao haicai no Brasil, e evidencia a origem francesa do haicai brasileiro ${ }^{10}$.

De acordo com Iura, há alguma controvérsia sobre qual teria sido o primeiro haicai escrito no Brasil. É provável que muitos poetas tenham experimentado o haicai desde o início do século XX, mas a primeira publicação significativa foi um ensaio de Afrânio Peixoto, de 1928, intitulado O haicai japonês ou epigrama lírico um ensaio de naturalização, ao qual se segue um apêndice de 49 haicais, muito provavelmente da autoria do próprio Afrânio, apesar de ele mesmo atribuí-los "ao mais íntimo de meus amigos". Vejamos dois exemplos:

COMPARAÇÃO

Um aeroplano

Em busca de combustível...

Oh! É um mosquito...
ANCH'IO
Na poça de lama
Como no divino céu
Também passa a lua.

Por outro lado, H. Masuda Goga, em A composição de haicai e amostras, é claro em afirmar que "tenha começado na década de 1920 o esforço de abrasileiramento do haiku, isto é, tentativas de exprimir em português as qualidades de concisão e mistério (sabor de haiku) dessa 
modalidade poética japonesa"11. Ele também ressalta que a mais antiga coletânea de haicai é Haicais, de Waldomiro Siqueira Júnior (um livro elegante, contendo 56 poemas, um poema por página), publicada em São Paulo, em janeiro de 1933.

Com os estudos dos poetas concretos Haroldo de Campos, Augusto de Campos e Décio Pignatari, em meados dos anos 1950, sobre o papel dos ideogramas na poesia japonesa, pela primeira vez o haicai entra no campo da universidade. Eles se esforçam de divulgar, publicar, traduzir e comentar o haicai japonês. Pela primeira vez, o haicai, que era considerado uma mera excentricidade exótica, ganhou respeito acadêmico e mereceu estudo sério por intelectuais brasileiros ${ }^{12}$.

$\mathrm{E}$, quanto ao haicai dos imigrantes japoneses, praticado em solo brasileiro, destaca-se Nempuku Sato (1898-1979), que chegou ao Brasil em 1927. Sato, um mestre de haicai discípulo do famoso Kyoshi Takahama, veio com a missão específica de plantar a semente do haicai no Brasil. Estima-se que tenha deixado 6 mil alunos entre os estados de São Paulo e Paraná. Kyoshi dedicou o

11 Goga (s. d.).

${ }^{12}$ Goga (s. d.).

${ }^{13}$ Iura (2000).

${ }^{14}$ Iura (2000). seguinte haicai a Nempuku quando de sua partida ${ }^{13}$ :

Kuwa totte haicaikoku o hiraku beshi

Lavrando a terra

Plante também

Um país de haicai.

O grande mérito de Nempuku foi pela primeira vez pesquisar os kigos (palavras de estação) da natureza brasileira, conseguindo assim aclimatar o haicai original a um novo país, pois o kigo é a alma do haicai tradicional. Também teve de reaprender tudo o que sabia sobre o haicai tradicional, por constatações tão simples como a de que o inverno é no meio do ano e o vento frio é o que vem do sul e não o contrário, como no Japão. Nempuku na verdade criou um novo haicai, totalmente brasileiro e adequado às condições da natureza e da terra brasileira ${ }^{14}$. 
Conforme os estudos de H. Masuda Goga (1988), podemos resumir cronologicamente as rotas do haicai no Brasil do seguinte modo: em 1879, por meio do livro Da França ao Japão, de Francisco Antônio Almeida; em 1908 , com a chegada dos imigrantes japoneses no porto de Santos; em 1919, com o livro Trovas populares brasileiras, de Afrânio Peixoto; em 1926, com o cultivo e difusão do haicai dentro da colônia japonesa; e, na década de 1930, pelo intercâmbio entre haicaístas japoneses e brasileiros, principalmente pelo próprio Goga.

Já que se toca no nome de Goga, seria importante voltar a Guilherme de Almeida, estabelecendo uma aproximação entre ambos. Goga, no prefácio ao livro Haicais completos, de Guilherme de Almeida, publicado pela Aliança Cultural Brasil-Japão, em 1996, detalha seu encontro com o "Príncipe dos Poetas Brasileiros" (título que recebeu em 1959, em votação popular).

Em 1952, Guilherme de Almeida assumiu o cargo de presidente da Comissão Executiva do IV Centenário de São Paulo, cujo escritório foi estabelecido no edifício dos Diários Associados, situado na rua Sete de Abril, no centro da cidade. Como repórter do Jornal Paulista diário bilíngue em japonês e português, publicado em São Paulo - Goga queria indagar se a referida comissão aceitaria a doação comemorativa a ser oferecida pela colônia japonesa aos cidadãos da capital bandeirante. Por esse e por outros motivos, avistou-se repetidas vezes com o responsável pela comissão, durante todo o período de preparação das festividades.

Goga conta que, na primeira entrevista, Guilherme lhe perguntou se apreciara a coletânea Poesia vária, publicada em 1947, e que continha haicais. "A minha resposta foi positiva. Ele ficou contentíssimo e começou a falar sobre o haicai." A seguir, explicou um aspecto linguisticamente semelhante que se observa nas duas línguas (português e japonês), citando como exemplos: "Leva-me esta carta / Ao meu namorado"; "Nem tudo o que é luz é ouro"; "Tanto dá até que fura". 
Guilherme queria mostrar-me que as frases faladas ou escritas em português de cinco ou sete sílabas não faltam no diálogo cotidiano ou na poesia popular, tal qual acontece no idioma nipônico. Por minha parte, fiz explanação sobre os conceitos mais importantes do haiku original, historicamente chamado "hokku", que exige o termo de estação do ano e dei-lhe o meu parecer sobre o título que se coloca para cada haicai. Entretanto, não toquei no assunto da rima, porque o haicai em língua luso-brasileira soa suave e agradável quando rimado. Apenas informei-lhe que o haiku original ignora a rima propriamente dita. Ele aceitou parcialmente o meu critério; sustentou, porém, o seu próprio ângulo e disseme que estaria contrariando, até certo ponto, a autoridade de Kyoshi Takahama, grande mestre do haiku e defensor do tradicionalismo. Acho que a atitude de Guilherme resida, talvez, na adaptação do haiku mais livre, a qual evitaria mera imitação do original ${ }^{15}$.

Conforme Goga, Guilherme mantinha relações de amizade com Kozo Itige (1894-1945), cujo nome haicaístico era Gyosetsu e que era cônsul-geral do Japão em São Paulo, no fim da década de 1930. Convidado pelo cônsul-haicaísta, teve oportunidade de assistir a reuniões de haiku, realizadas por pessoas ligadas ao mestre Keiseki Kimura (1867-1938), que liderava um grupo de "haijin" paulistano.

Quando teve lugar o simpósio sobre cultura japonesa, em comemoração ao 60 ำ aniversário da imigração japonesa para o Brasil, em 18 de junho de 1968, Guilherme foi convidado como um dos palestrantes pelo centro de Estudos NipoBrasileiros de São Paulo, organizador do evento, e do qual sou associado. Esperei, até o último momento, a sua presença; mas, por algum motivo, ele não compareceu.

Relembrando-me, agora, daquela troca de ideias sobre o haicai, devo reconhecer o esforço dinâmico do saudoso Príncipe dos Poetas Brasileiros: sem dúvida, ele estimulou o abrasileiramento da mais concisa poesia de origem japonesa ${ }^{16}$.
${ }^{15}$ Goga (1996).

Prefácio ao livro

Haicais completos, de Guilherme de Almeida.

16 Goga (1996).

Prefácio ao livro

Haicais completos, de Guilherme de Almeida. 
Guilherme de Almeida considerava que, para produzir o haicai, era preciso não só ter qualidades, mas também passar por uma grande iniciação. Ele a teve em São Paulo, em 1937, quando foi conduzido pelo então cônsul do Japão em São Paulo e poeta, Kozo Itigé, ao Clube Japonês, cuja sede era na rua da Liberdade. Nesse clube realizavam-se verdadeiros jogos florais. Doze poetas reunidos em torno de uma mesa, na terceira quarta-feira de cada mês, apresentavam cada um o seu haicai sobre um tema sorteado com um mês de antecedência. Esses haicais eram postos em concurso, sendo premiado o melhor. "Lembro-me de que nessa reunião em que estive o tema dado anteriormente era este: 'Brisa de primavera'”. Nessa ocasião, Guilherme ouviu haicais muito interessantes apresentados pelos poetas japoneses residentes em São Paulo: "empregados no comércio uns, pequenos lavradores nos arredores da Capital outros, gente humilde mas de uma invejável cultura. Aliás, no Japão, a poesia quase que é obrigatória para todas as classes... As gueixas do Yoshiwara são todas poetisas de valor... Traduzi mesmo várias poesias dessas mulheres, como Cançôes de gueixas, que figuram no meu livro Acaso. Por exemplo: "Esconderijo":

Nada de mágoas, nem queixumes!

Escondo-me na minha felicidade

como os vaga-lumes que, quando querem se ocultar, buscam a claridade de um raio de luar..."17

Neste ponto, a intenção é deter-se um pouco sobre a figura de Matsuó Bashô (1644-1694), talvez o principal nome do Japão relacionado à prática do haicai, e, a partir dele, aprofundar algumas questões relacionadas ao haicai. Bashô viveu no período Genroku, no Japão medieval. Era samurai, guerreiro defensor da nobreza feudal. Após a morte de seu senhor, tornou-se Rônin, ou seja, um samurai sem mestre. Em Edo (hoje a cidade de Tókio), trabalha em um cargo público, na função de superintendente de águas, mas por pouco tempo. A partir daí, contando 23 anos, vai 
levar a vida como instrutor de haicai e monge budista, viajando a pé, sem destino, sustentado por milhares de discípulos (3.000 aproximadamente). Um detalhe: entre uma andança e outra, aos 38 anos, morou provisoriamente numa cabana em Fukagawa, diante de uma plantação de bananeiras (bashô-on), o que explica seu apelido.

Bashô interessou-se logo por essa estrutura concentrada, "cápsula carregada de poesia, capaz de fazer saltar a realidade aparente" 18 , denominada haicai, a fim de ver, conforme um poema de Paulo Leminski,

um pouco de mao

em todo poema que ensina

quanto menor

mais do tamanho da china

Leminski escreveu um ensaio/biografia sobre ${ }^{18}$ Paz (1990, p. 163). Bashô, e usa como epígrafe uma passagem do conto borgiano Tlön, Uqbar, Orbis Tertius, que pode ajudar a entender melhor o significado do que seja um haicai:

...e um cone de metal reluzente, do diâmetro de um dado. Em vão, um menino tentou levantar esse cone. Só um homem conseguiu. Eu o tive na palma da mão alguns minutos: recordo que seu peso era intolerável e que depois de largado o cone, a opressão durou. Também recordo o círculo preciso que me gravou na carne. Essa evidência de um objeto muito pequeno e, ao mesmo tempo, pesadíssimo deixava uma impressão desagradável de asco e medo. ${ }^{19}$

O haicai é poema curto de 17 sílabas, formado por três versos, o intermediário com sete e os outros dois com cinco sílabas cada. É uma variação do tanka, poema de 31 sílabas, do qual conservou os três primeiros versos. Como assinala Octavio Paz, do ponto de vista formal o haicai divide-se em duas partes: "uma da condição geral e da ubiquação temporal ou espacial do poema" (outono ou primavera, árvore ou rochedo), e outra "relampagueante, que deve conter um elemento ativo" 20 . Esta, inesperada; 
${ }^{21}$ Campos (1977, p. 57).

22 Leminski (1986a, p. 98). a outra, descritiva e quase enunciativa. É do atrito entre ambas que comparece, no poema, a poesia. Como sublinhado por Donald Keene e Haroldo de Campos ${ }^{21}$, o haicai relaciona dois elementos básicos, um de permanência (a condição geral, por exemplo a primavera) e outro de transformação, que vem a ser a percepção momentânea. Para Leminski,

o mundo que o haicai procura captar é um mundo objetivo, o mundo exterior. Um mundo de coisas onde o eu está quase sempre ausente, sujeito oculto, elidido. Mas não é um mundo morto, uma mera descrição. Por trás das objetividades do haicai, sempre pulsa (sem se anunciar) um Eu maior, aquele eu que deixa as coisas ser, não as sufoca com seus medos e desejos, um eu que quase se confunde com elas. A esse estado, os poetas japoneses de haicai chamam "mu-ga", em japonês, "não eu", o exato ponto de harmonia entre um eu e as coisas. "Não eu" é o estado perfeito para fazer haicai. Os mestres japoneses gostavam de dizer que o bom haicai ninguém faz. Ele se faz sozinho, a hora que quiser; tudo o que o poeta pode fazer é suspender os egoísmos da subjetividade para permitir que a realidade se transforme em significado. ${ }^{22}$

Poema sintético, econômico, concentrado e compacto, o haicai é a expressão verbal de um pequeno satori. Corresponde a uma exclamação de surpresa e encantamento diante de qualquer aspecto da natureza. É o que explica um de seus maiores especialistas, Kenneth Yasuda:

Sabemos que, quando acontece a uma pessoa ver um belo pôr do sol ou lindas flores, por exemplo, ela fica tão encantada que apenas permanece imóvel. Esse estado mental pode ser chamado de "ah-idade", pois aquele que o experimenta só pode soltar uma funda exclamação de deleite: "Ah!". O objeto capturou-o e ele está apenas atento às formas, às cores, às sombras, aos matizes. Por um breve momento, ele vê uma configuração, uma significação que nunca tinha visto antes, naquele objeto. 
A intenção do haicai é fixar essa experiência de agradável surpresa diante da "realização do real"23.

Segundo Roland Barthes, "o haicai é um momento feliz em que a linguagem se detém, pousando na formulação justa"; o que o haicai diz é apenas: "é isso". Perfeita comunhão do sujeito com o objeto, da percepção com o real, da linguagem com a coisa: satori" ${ }^{24}$.

Coincidência entre o Eu e as coisas, o haicai tenta, então, "extrair o máximo de significado do mínimo de material, em ultra-segundos de hiperinformação"25. Já Octavio Paz nos dá duas definições pertinentes: em primeiro lugar, para o efeito produzido pelo haicai: "sua poesia [do haicai] é um verdadeiro calmante, embora a sua não seja uma calma que não se parece nem com o letargo da droga nem com a modorra da digestão. Calma alerta e que nos torna leves"26.

Em seguida, o significado da poesia de Bashô:

A poesia de Bashô não é simbólica: a noite é a noite e mais nada. Ao mesmo tempo, é algo mais, algo que, rebelde à definição, recusa-se a ser nomeado. O haiku é crítica da realidade: em toda realidade há algo mais do que chamamos realidade; simultaneamente, é uma crítica da linguagem. ${ }^{27}$

Por vários motivos, Bashô é considerado um dos maiorespoetasjaponeses:nestaarte "saturada de sabi(poemas caracterizados pelo clima de solidão e tranquilidade) e wabi (conota solidão, mas desta vez com referência ao estado emocional da vida do eremita, do asceta)"28, ele procurou combinar os ideais do confucionismo com a reverência budista; sobretudo, "elevou o haicai ao estatuto de um $d \hat{o}$, ou seja, de um caminho de vida, uma forma de ver e viver o mundo"29. É preciso lembrar que,

quando [Bashô] começou a escrever, a poesia tinha se convertido em passatempo: poema queria dizer poesia cômica, epigrama ou jogo de salão. Bashô recolhe esta nova linguagem coloquial, livre e desimpedida, e com ela procura o mesmo que os antigos: $\mathrm{o}$ instante poético ${ }^{30}$.
${ }^{23}$ Perrone-Moisés (1990, p. 134).

${ }^{24}$ Apud Perrone-

Moisés (1990, p. 134).

${ }^{25}$ Leminski (1986a, p. 98).

${ }^{26} \operatorname{Paz}$ (1990, p. 170).

27 Paz (1990, p. 166).

${ }^{28}$ Franchetti (1991, p. 21).

${ }^{29}$ Franchetti (1991, p. 18).

${ }^{30}$ Paz (1990, p. 158). 
31 Blyth (apud

SVANASCINI, 1987.

p. 8).

${ }^{32} \mathrm{Paz}(1990$, p. 160

161).

${ }^{33}$ Na tradução de

Franchetti (1991, p. 89).

34 Leminski (1983d, p. 39).
O fato de Bashô ser budista é fundamental para compreender as ligações profundas entre o haicai e a filosofia Zen. Como afirma Blyth, um dos maiores estudiosos e tradutores de haicai, "se dizemos que o haicai é uma forma de zen-budismo, não quer dizer que afirmemos que o haicai pertença ao zen, mas sim que o zen pertença ao haicai" ${ }^{31}$. O Zen surgiu no século VI, no Japão, mas só a partir do período Muromachi (1333-1600) é que atingirá uma grande força na cultura japonesa.

Para os samurais, Zen era o outro prato da balança. Em um extremo, o estilo de vida bushidô, isto é, o estilo do guerreiro vertido para o exterior; no outro, a cerimônia do chá, a decoração floral, o teatro Nô e, ao mesmo tempo, a meditação Zen. ${ }^{32}$

Em Bashô, o haicai. No kaikai, o Zen. Essa equação não foi ignorada por Guilherme de Almeida. Em linhas gerais, mesmo os seus poemas que não seguem a forma do haicai ocidentalizada carregam consigo a carga de rigor e concisão tributária do haicai, caras também à forma ocidental do soneto.

Como transpor para o mundo ocidental toda a complexidade formal do haicai? Para grafar o japonês, é necessário usar kanki, ideogramas de origem chinesa, mais um silabário, o hirakaná, como se observa no famoso haicai de Bashô:

\begin{tabular}{|c|c|}
\hline $\begin{array}{l}\text { furu-ike ya /kawazu tokikomu } \\
\text { velho poço, /rã pula [na água] } \\
\text { tanque de peixes, } \\
\text { lagoa pequena }\end{array}$ & $\begin{array}{l}\text { /mizu no oto } 33 \\
\text { /barulho de água }\end{array}$ \\
\hline
\end{tabular}

Além disso, o idioma japonês é aglutinante, maleável ao extremo para a composição de palavrasmontagem. São as kake-kotoba, literalmente, "palavra pendurada". Esse efeito de linguagem "é a passagem de uma palavra por dentro de outra palavra, nela deixando seu perfume. Sua lembrança. Sua saudade"34. Na tradução, muitas vezes, ocorre uma impossibilidade de contar com essas riquezas, ideogramas, kake-kotobas. Por outro 
lado, os haicais de Guilherme de Almeida se ajustam de modo natural ao recurso estilístico tradicional da rima, um imperativo para o poeta produzir haicais à brasileira; e, eventualmente, podem não obedecer à estrutura convencional de um haicai, como se depreende da análise, feita por Leminski, do mais conhecido haicai de Bashô:

$\mathrm{O}$ velho tanque - o primeiro verso expressa, em geral, uma circunstância eterna, absoluta, cósmica, não humana, normalmente, uma alusão à estação do ano.

O sapo salta $-O$ segundo verso exprime a ocorrência do evento, o acaso da acontecência, a mudança, a variante, o acidente casual. Por isso, talvez, tenha duas sílabas a mais que os outros.

O som da água - A terceira linha do haicai representa o resultado da interação entre a ordem imutável do cosmos e o evento. Resultado distinto da conclusão grega aristotélica. O terceiro verso de um haicai não é uma conclusão lógica: parte de uma obra de arte, é o membro de um poema. ${ }^{35}$

${ }^{35}$ Leminski (1983d, p. $42-45)$.

${ }^{36}$ Barthes (1989, p. 57).

No entanto, se por um lado o haicai proposto por Guilherme de Almeida é diverso, sob o ponto de vista da estrutura, do praticado por Bashô ou qualquer outro poeta japonês, compartilha da visão de Barthes:

Quando nos dizem que foi o ruído da rã que despertou Bashô para a verdade do Zen, pode entender-se (embora se trate de uma maneira muito ocidental de falar) que Bashô descobriu nesse ruído certamente não a causa de uma "iluminação", de uma hiperestesia simbólica, mas, em seu lugar, um limite da linguagem: há um momento em que cessa a linguagem (momento alcançado graças a um prolongado exercício), e é este corte sem eco que institui ao mesmo tempo a verdade do Zen e a forma, breve e leve, do haiku. ${ }^{36}$

Algumas traduções, para o português, do haicai de Bashô: 
o velho tanque

rã salt'

tomba

rumor de água (Haroldo de Campos)

VELHA

LAGOA

UMA RÃ

MERG ULHA

UMA RÃ

ÁGUAÁGUA (Décio Pignatari)

velho lago

mergulha a rã

fragor d'água (Alberto Marsicano Rodrigues)

37 Pereira Filho (1941).

O velho tanque-

uma rã mergulha,

Barulho de água (Paulo Franchetti e Elza Doi)

Nem grilo, grito, ou galope;

No silêncio imenso

Só uma rã mergulha - plóóp! (Millôr Fernandes)

um salto de sapo

jamais abolirá

o velho poço

(Paulo Leminski)

Para Guilherme de Almeida, a melhor definição para haicai é dos próprios japoneses: "o haicai é a anotação poética e sincera de um momento de elite" 37 . Note bem: anotação breve e poética. E pela sua qualidade de ser poesia espiritual, sincera, não pode deixar de ser feita no momento: no verão não se faz um haicai da primavera. Além do mais, é de um momento de elite" . Guilherme cita como exemplo perfeito o haicai de Bashô, em tradução livre: 
No tanque morto

há o ruído de uma rã

que mergulha.

Esse haicai tem o título de "Solidão", e o titulo no haicai é como o verbete num dicionário: o texto definirá o título. Na entrevista concedida a Genésio Pereira Filho (1941), o repórter instiga: o haicai exige do próprio leitor um alto senso poético. Em caso contrário, jamais poderá penetrar a essência dessa poesia. No que Guilherme responde:

Exatamente. O haicai citado é um exemplo. Que relação haverá entre uma rã que mergulha num tanque morto com a solidão? Entretanto, acho que não há definição mais perfeita de solidão do que a que se contém nesse haicai. Veja-se mentalmente o desenho: numa água estagnada - tanque morto a rã que mergulha abrindo em torno dela círculos concêntricos que se prolongam indefinidamente até às margens... Ora, não há nada mais "sozinho" no mundo do que o centro de uma circunferência; porque ele é único. A circunferência só pode ter um centro que só pode estar equidistante de todo o ponto da circunferência ${ }^{38}$.

Além dessa poética da brevidade, o que mais atraiu Guilherme de Almeida a cultivar essa forma oriental? Formulando a pergunta de outro modo, o que leva um poeta do século XX, com raízes clássicas e modernistas, aos braços de uma poesia próxima do haicai? De acordo com Leyla Perrone-Moisés,

Os caminhos pelos quais o animal falante busca situar-se, e conviver com a brecha do seu desejo impossível, dão voltas recorrentes e, em determinados pontos, enfrentam as mesmas encruzilhadas. Mas esses caminhos não têm volta, no tempo ou no espaço. O Japão, como diz Octavio $\mathrm{Paz}$, torna-se, para o poeta moderno, "não um espelho, mas uma janela que nos mostra outra imagem do homem, outra possibilidade de ser"39.

38 Pereira Filho (1941).

39 Perrone-Moisés (1990, p. 157). 
No equilíbrio entre esses dois traços característicos avança o poeta, e aqui ele marca uma de suas singularidades. A forma breve, percebe Guilherme, é o melhor meio de expressar aquilo que o Zen define como iluminação (satori em japonês e sambodhi em sânscrito): "aqui e agora, um instante que é todos os instantes, momento de revelação em que o universo inteiro - e com ele a corrente de temporalidade que o sustenta - se desmorona"40: um momento concentrado que denota as coisas em um estado puro, tocadas em sua essência, flagradas no instante mesmo em que se definem por elas mesmas, instante em que o é é. Como se o poeta estivesse possuído pelo mesmo sentimento de Clarice Lispector:

Cada coisa tem um instante em que ela é. Quero apossar-me do é da coisa. Esses instantes que decorrem no ar que respiro: em fogos de artifício eles espocam mudos no espaço. Quero possuir os átomos do tempo. E quero captar o presente

${ }^{40} \mathrm{Paz}(1990$, p. 160).

${ }^{41}$ Lispector (s. d.). que pela sua própria natureza me é interdito: o presente me foge, a atualidade me escapa, a atualidade sou eu sempre no já. ${ }^{41}$

Para Bashô, o haicai é "simplesmente o que está acontecendo aqui, agora”. É nesse sentido que Guilherme incide seu foco nos mínimos e imperceptíveis fatos e coisas, largados à deriva do dia a dia, e que acabam evidenciados pelo poder revelador que as coisas carregam em si mesmas, desnudadas pelo poeta.

Daqui, somos levados a outra questão, que se confunde com a do poema como registro do "aqui e agora", questão sendo colocada, em outro plano - um plano histórico, a presentificação do tempo, elidindo passado e futuro, aquilo que Guilherme de Almeida destacou na definição do haicai, o "momento de elite", uma espécie de Grande Presente em que o ato poético deverá se inserir:

O poema traça uma linha divisória que separa o instante privilegiado da corrente temporal: nesse aqui e nesse agora principia algo: um amor, um 
ato heróico, uma visão da divindade [...]. Esse instante é ungido com uma luz especial: foi consagrado pela poesia, no melhor sentido da palavra consagração. ${ }^{42}$

Essa consagração do instante, da qual o poema é sujeito, é expressa na seguinte passagem de Décio Pignatari:

...[no] processo verbal de pura e absoluta nadificação das coisas, Mallarmé parece abolir passado e futuro e atingir o grau zero do tempo: o "presente absoluto das coisas", "le présent absolu des choses". [...] O eterno e o infinito encapsulados no instante. Que passa. E não passa. Não sem razão, já houve quem aproximasse esse esforço verbo-mental de Mallarmé aos processos anti-verbo-mentais da mística oriental. ${ }^{43}$

"Presente absoluto das coisas", "consagração do instante", o poema é o "Grande Presente", memória e projeto interligados. Isso só confirma, em Guilherme de Almeida, a existência de uma visão ligada à filosofia Zen, "que valoriza o cotidiano e a instantaneidade, a materialidade e a imediatidade da experiência, contra a pobreza do pensamento conceptual e a tirania do mundo das palavras" 44 . Nesse sentido, o poeta Paulo Leminski compara o haicai à fotografia, aquele sendo "um clique de palavras". O poeta ressalta duas características comuns à foto e ao poema japonês. A primeira seria a irrepetibilidade, assim definida:

o ideograma é traçado num só gesto, único, irremediável, absoluto: não pode ser corrigido. Entre os mestres do haicai, sempre foi enfatizada essa imediatidade irrepetível e incorrigível. $\mathrm{O}$ verdadeiro haicai é aquele que desponta de súbito, inteiro, íntegro, sólido objeto do mundo, num momento decisivo que não depende da vontade, do arbítrio do poeta. Como o ato de bater uma foto. ${ }^{45}$
$42 \operatorname{Paz}(1990$, p. 53).

43 Pignatari (1995, p. 31).

${ }^{44}$ Leminski (1986a, p. 98).

${ }^{45}$ Leminski (1986a, p. 98). 
A segunda característica seria a intraduzibilidade, já que "o que é irrepetível não pode ser traduzido, vertido, passado para outro sistema de signos. Fotos e haicais são coisas, coisas não têm tradução" ${ }^{\text {" }}$. Assim, a poética de Guilherme de Almeida sugere, em vários momentos, trazer a marca desses eventos irrepetíveis e intraduzíveis, como sendo, em parte, a migração do acontecimento fortuito (o acaso) para o registro no poema. $\mathrm{Ou}$, como Guilherme fixou, em um haicai:

\section{INFÂNCIA \\ Um gosto de amora \\ comida com sol. A vida \\ chamava-se "Agora".}

Guilherme de Almeida tinha como mais alto

${ }^{46}$ Leminski (1986a, p. 98). valor a noção dessa característica do haicai, bem como a necessidade de rigor da criação. É o que está registrado em outro momento de sua entrevista concedida a Genésio Pereira Filho:

Escrevi o meu primeiro haicai no dia 13 de agosto de 1937 e até hoje, 13 de maio de 1941, só consegui fazer quarenta e três haicais. É pouco, mas é assim... Exuberante poeta nacional, em uma semana, publicou trezentos e cinquenta haicais!!... (ponha assim mesmo, dois pontos de admiração e reticências...). Duvido que essas composições sejam "anotações poéticas e sinceras de momentos de elite...". E por falar em momento de elite, tenho que acreditar nele. É que ele tem que ser aproveitado no instante mesmo a sua sinceridade. Cito um caso que se passou comigo mesmo. Em março de 1938, vi uma quaresmeira, florida, maravilhosa. Era à tardinha, a luz já oblíqua do quase outono faz ajoelhar-se aos pés da árvore a sua sombra. Lembrei-me das imagens de quaresma - vestidas de roxo nas igrejas. O haicai ocorreu-me incontinenti. Eu estava num ônibus; ia construindo mentalmente, improvisando, pois que o haicai é sempre improvisado. Foi quando 
um conhecido, um amigo - antes um inimigo - , isto é, o homem que explica, cortou-me o pensamento. Apontou-me a árvore, comentando a sua beleza e dando-lhe o nome técnico, botânico da quaresmeira. Quando cheguei em casa, à noite, quis refazer o haicai. Inútil. Por mais de três horas nesse afã, nada consegui. Saiu um outro haicai, inspirado numa estrelinha que, pela minha janela eu avistava. Estava cochilando e esse movimento de pender e levantar a cabeça, de abrir e fechar os olhos... de "piscar"... "pescar"...

\section{PESCARIA}

Cochilo. Na linha

Eu ponho a isca de um sonho.

${ }^{47}$ Pereira Filho (1941). Pesco uma estrelinha ${ }^{47}$.

Uma forma poética: o haicai. Um poeta: Guilherme de Almeida. O Japão no Brasil. O Brasil no Japão. Um belo diálogo sem fim. 


\section{Referências}

ALMEIDA, Guilherme de. Poesia vária. São Paulo: Livraria Martins Editora, 1947.

ALMEIDA, Guilherme. Toda a poesia. São Paulo: Livraria Martins Editora, São Paulo, 1952. 6 v.

BARTHES, Roland. O kaiku e Bashô. In: SAVARY, Olga (Trad. e org.). Hai-kais de Bashô. São Paulo: Hucitec, 1989.

CAMPOS, Haroldo de. A arte no horizonte do provável. São Paulo: Perspectiva, 1977.

FERNANDES, Millôr. Hai-kais. Rio de Janeiro: Nórdica, 1986.

FRANCHETTI, Paulo et al. Hai-kai: Antologia e história. Campinas: Ed. da Unicamp, 1991.

GUTTILLA, Rodolfo Witzig. Haicai gauche. In: Caderno Pensar. Belo Horizonte: Estado de Minas, 1ำ nov. 2008, p. 6.

LEMINSKI, Paulo. Matsuó Bashô. São Paulo: Brasiliense, 1983.

LEMINSKI, Paulo. Anseios crípticos. Curitiba: Criar, 1986.

PAZ, Octavio. Signos em rotação. Trad. Sebastião Uchoa Leite. São Paulo: Perspectiva, 1990.

PERRONE-MOISÉS, Leyla. Caeiro Zen. In: Fernando Pessoa: aquém do eu, além do outro. São Paulo: Martins Fontes. 1990

PIGNATARI, Décio. Letras, artes, mídia. São Paulo: Globo, 1995.

SANCHES NETO, Miguel. Abandono. Ponta Grossa (PR):

Edição do Autor, 2003. 
SAVARY, Olga. O livro dos hai-kais. 2. ed. Prefácio de Octavio Paz e tradução de Olga Savary. São Paulo: Aliança Cultural Brasil-Japão/Massao Ohno, 1987.

SVANASCINI, O. In: SAVARY, Olga (Trad. e org.). Hai-kais de Bashô. São Paulo: Hucitec, 1989.

\section{Documentos eletrônicos}

GOGA, H. Masuda. A composição de haikai e amostras. Disponível em: <www.kakinet.com/caqui/brasil5.htm.>

GOGA, H. Masuda. Guilherme de Almeida e eu. Disponível em: <www.kakinet.com/caqui/gago.htm>

IURA, Edson Kenji. O Haicai Brasileiro. Disponível em: <www.sumauma.net/gremio/palestra-edson.html>

PEREIRA FILHO, Genésio. Haikai, poesia de estação:

entrevista com Guilherme de Almeida. 1941. Disponível em: <www.ihgsp.org.br/site/guilherme_tunel.htm> 
